\title{
Humanity
}

\section{Time Travel}

\section{Sara R. Ahronheim, BScH, MDCM, FRCPC, CSPO, MOT}

Tonight, we watched the space station fly over our house, with a sliver of yellow new moon shining nearby. Wide-eyed the children listened to me describe the astronauts living inside, looking down at us from up high. The wonder, the innocence of being so little and not knowing at all what the grown up next to you is telling you, imagining a reality you cannot even begin to perceive-it is magical.

When I was a child, I believed in magic. I trusted bees not to sting, carried ladybugs on my palms, sheltered worms in mud-filled tupperwares in the backyard. I thought the world moved around me, that somehow all was good and right. When kids began to tease me at day camp and, suddenly, my world was not safe and perfect, I still truly believed that if I was just nice, and kind, the boys would not push me off my bike at speed on the street. If I was sweet, they wouldn't hold my head under water at the pool until the lifeguard whistled. If I asked them to stop, they wouldn't spit on me or chase me down the street till I fell.

As I grew up, those boys faded away; at 18, I left for university and forgot them, left them behind. They weren't important, they were shadows in the past of a childhood that was light and air and sunshine around the corners of their nastiness. I was a happy, free, innocent, and playful kid with lots of other friends, so as I grew up, the bullies occupied only the tiniest part of my memories.

But I never forgot their names. Three, in particular, still sit at the tip of my tongue. K., R., and J. were the meanest of the mean back then in those sun-filled sticky summers, and every now and then, I did wonder where they went. Did they grow up good? Did they end up in jail? Who did they hurt after me? Did they regret being the bullies they were?

Today, I learned what happened to one of them.
My day was somewhat remarkable at work; early in the day, I encountered an old teacher of mine from grade school. A lovely lady, poised and elegant, always pleasant and warm in my memories, accompanied her elderly husband for a relatively benign reason to my emergency department. Seeing them was a rose, a sweet moment in my day, lighting my morning with joy.

In the afternoon, a punch to the gut when I saw his name on the next chart to be seen. No way, it can't be, but I knew with a glance at his birthdate that it was. The bully of my childhood, now a man, a troubled one, was waiting to be assessed in the psychiatry back hallway. He had been suffering for years with a psychiatric disorder, at times aggressive, at times psychotic; his disease made sense to the little girl inside me who suffered from blows and knocks off her bike. A bad boy grew into a man with a mental illness: how long was his illness undiagnosed? Was he sick when we were young? Is that why?

Prepared for anything I did what I always do when I go into the psych rooms: I removed my stethoscope from around my neck and placed it in a pocket, hid my pens in back pockets or underneath clothing, and took all precautions not to be injured by an errant patient. My stomach in knots, doing back flips of nausea from recollections of pain, I pushed it all away and went to face my patient.

"Hi sir, my name is Dr. A., can we sit over here and talk about why you're here?"

Calmly and quietly, he joined me, meek, eyes cast downward, he spoke softly.

"I don't feel right. My heart feels weak."

Slowly I drew out of him the story, learned he has been unstable, not well, needing help.

Stethoscope out, I touched my patient, one warm hand on his shoulder as I heard for the first time the beating of his heart. The same heart, that beat when his fists

\footnotetext{
From: Jewish General Hospital, McGill University, QC.
}

Correspondence to: Dr. Sara Ahronheim, Department of Emergency Medicine, Jewish General Hospital, Room H-190, 3755 Cote Sainte Catherine, Montreal, Quebec, H3T 1E2; Email: Sara.ahronheim@mcgill.ca

(c) Canadian Association of Emergency Physicians 2020

CJEM 2020;22(3):389-390

DOI 10.1017/cem.2019.461 
hit me, so many years ago. The same heart, that carried him from a troubled childhood to an even worse future. A strong heart, a beautifully beating musical heart giving life to this tormented, beaten down, sad man seated with his health in my hands. His heart knocked the breath from my own chest, and I planted my feet solidly so not to fall.

The magic of my childhood felt palpable in my fingers; the silvery string of time and fate shimmering between us as we spoke.

I wish I could feel like he deserves this life.

I wish I could feel vindicated.

I tried to feel like "karma's a bitch," I even said it to myself, but I couldn't feel it. I don't feel it.

No one deserves to live a tortured life. Mental illness, likely untreated in childhood, now eating him up inside-how devastating.

I walked out of that hallway feeling quite empty. His sadness like acid in my mouth, his loneliness like stones in my belly.
So, now, I know where he went, when he dissolved to shadows in my frame of existence. But knowing, and knowing what I know as a physician, only makes the memories even more sorrowful. I wonder if anyone knew, when he was young, and if anyone could have helped. It is all speculation, hidden in the fabric of time, and I will never know.

Looking at the cosmos tonight with my children, watching their eyes sparkle in the moonlight, hearing their laughs and feeling the music of their souls, I made peace with that little boy in the past. He sleeps quietly in my mind, and I pray for the same quiet in his all grown up soul, tonight and always. If magic exists, I hope my hand on his arm passed some of it inside to heal him, in ways no medicine ever could.

Keywords: Bullying, family, medicine, mental health

Competing interests: None declared. 